\title{
ENVIRONMENTAL ASSESSMENT OF THE STATE OF TRANS-BOUNDARY WATERSHEDS OF THE DNIEPER
}

\author{
V. Pichura ${ }^{1}$, Y. Pilipenko ${ }^{1}$, E. Domaratsky ${ }^{1}$, A. Gadzalo² \\ ${ }^{1}$ Херсонський державний аграрний університет \\ ${ }^{2}$ Інститут агроекології і природокористування НААН
}

\begin{abstract}
Стратегічна екологічна оцінка (CEO) є надійним інструментом у забезпеченні стійкості навколишнього середовища країн транскордонних басейнів. Директива 2001/42/ЕС визначає зобов'язання органів державного управління (або тих приватних організацій, що надають публічні послуги) щодо визначення та оцінки потенційно значущих екологічних наслідків пропонованих планів та програм (не політики), у т.ч. у сфері транскордонного співробітництва, з метою послаблення або уникнення потенційно значущого негативного впливу на навколишнє природне середовище ще до ухвалення такого плану або програми. Річка Дніпро є однією із найбільших річок Європи, басейн якої має 511 тис. км ${ }^{2}$ і розташований у межах трьох держав - Російської Федерації (19,8\% від загальної площі басейну), Республіки Білорусь (22,9) та України (57,3 \%). 3 огляду на соціально-економічний стан транскордонних країн, екологічна ситуація в басейні Дніпра є стабільно нестійкою. Встановлено, що для розв'язання екологічних проблем транскордонної річки найбільш перспективним є практичне науково обгрунтоване впровадження басейнових принципів природокористування, яке передбачає використання комплексного підходу до організації земле- та водоохоронних заходів, з урахуванням системності досліджень. В основу завдання дослідження покладено здійснення СЕО просторово-часової трансформації ландшафтних екосистем водозбірної території р. Дніпро на основі принципів басейнового підходу. Стратегічна екологічна оцінка і просторове групування здійснено за шістьма показниками агрогенної трансформації структурно-функціонального стану ландшафтних екосистем басейну Дніпра: лісистість, розораність, площі схилів понад $1^{\circ}$, площі схилів південноі експозищії, площі розораних схилів, площі еродованих орних земель. За результатами СЕО і геомоделювання визначено, що понад 50\% території басейну Дніпра має високу агрогенну трансформацію структурно-функціонального стану ландшафтних екосистем. Головним критерієм дестабілізації агроландшафтів є висока розораність, для вирішення питання найефективнішим інструментом покращення екологічного балансу території транскордонного басейну є скорочення орних земель на користь інших угідь або екологічного фонду в межах 470 суббасейнів із загальною площею 346, 3 тис. км ${ }^{2}$ $(\sim 67,8)$. Раціональне землекористування відповідно до СЕО повинно враховувати властивості і особливості ландшафту, сприяти охороні і відтворенню грунтового, рослинного покриву та інших природних компонентів у співробітництві і узгодженні між держсавами транскордонного басейну.
\end{abstract}

Ключові слова: стратегічна екологічна оцінка, сільськогосподарська освоєність, лісистість, ерозійний потенціал, річкові басейни, річка Дніпро, геомоделювання, ГІС-технології.

In recent years, the need and importance of operations of the strategic level, aimed at regulating and ensuring environmental sustainability of geo-hydro system of trans-boundary basins are growing. To ensure a comprehensive approach to the environmental assessment and management of trans-boundary basins the environmental assessment methods have been set that require

(C) V. Pichura, Y. Pilipenko, E. Domaratsky, A. Gadzalo, 2017 constant improvement and amendments by the principles adapted to policies, plans and programs of neighboring countries, primarily in the areas of trans-boundary basins. In European practice, evaluation of policies, programs and development plans and ensuring environmental sustainability units Directive 2001/42 /EU «On Strategic Environmental Assessment» is used. Strategic Environmental Assessment (SEA) is the main instrument for integrating environmental considerations (in- 
cluding health) in the development of plans and programs. SEA promotes sustainable development through the promotion of environmental issues in economic and social development and the integration of green economy objectives and sustainable consumption and production in the strategic decision making.

After Ukraine signed the Protocol on Strategic Environmental Assessment in 2003 to the Convention on the assessment of the environmental impact in a trans-boundary context, some national and local authorities used the SEA in the strategic planning. Ratification of the Protocol and implementation of procedures for strategic environmental assessment provided by the National Action Plan on Environmental Protection for 20112015, approved by the Cabinet of Ministers of Ukraine dated 25.05.2011 No. 577-p, and the National Program of Ukraine to the EU legislation as Protocol reflects the approach adopted at the EU level and enshrined in Directive 2001/42/EU. In 2013, Ukraine has developed new legislation on SEA (draft Law of Ukraine «On Strategic Environmental Assessment» and «On Ratification of the Protocol on Strategic Environmental Assessment to the Convention on the Assessment of the Environmental Impact in a Trans-Boundary Context», agreed with the concerned central executive government and submitted to the Ministry of Foreign Affairs for further approval to the President of Ukraine), which creates the need for wider integration of SEA in planning processes at national and regional levels through training, development of procedures related to SEA, and exchange of the best practices.

The issue of the need, development, and methodological development of the direction and feasibility of using strategic environmental assessment was studied by the scientists: E. Ashykova, B. Burkynskyi, E. João M. Partidario, B. Sadler, A. Cherp V. Karamushka L. Nilsson, D. Palehov, T. Fischer, N. Humarova, E. Khlobystov and other scientists [1-3].

The analysis of the research shows that in ensuring the environmental policy of Ukraine and on the way towards European integration it is necessary to create the conditions (infor- mation, investment attractiveness, economic justification, etc.) for mandatory strategic environmental assessment during the development of plans and programs and at strategic planning.

Strategic environmental assessment is an important tool for planning and decisionmaking to ensure sustainable development. SEA is also a systematic process used in making decisions that takes into account the impact of human activity on the environment. This process accounts for the environmental impact of development proposals, programs, etc., takes into account costs, resource requirements, labor. The process includes an assessment of potential impacts of the proposed project, policy or program on the ecosystem air, water, land and living organisms. It also provides for study of the effects of socio-economic nature to the public. These assessments provide a sound basis for limiting or eliminating the negative impact on the environment when making strategic decisions.

SEA is referred to a number of analytical approaches and approaches based on participation, aimed at integrating environmental considerations into policies, plans and programs and evaluate internal relations of economic and social aspects. SEO can be defined as a set of approaches that use a variety of tools, not a single, fixed and prescriptive approach. Good SEA is adapted, developed in accordance with specific conditions in which it is applied. This can be seen as a continuum enhanced integration: at one end of the continuum is the principal aim to integrate into the process of strategic decision-making environmental problems at the same level with economic and social problems; on the other side the emphasis of the problem is put on the full integration of environmental, social and economic factors in a comprehensive assessment of sustainability.

Strategic Environmental Assessment (SEA) is a reliable tool in ensuring the environmental sustainability of trans-boundary basins. Directive 2001/42/EU defines the obligations of the government (or those of private organizations that provide public services) to identify and assess potentially 
significant environmental effects of the proposed plans and programs (not politicians), including cross-border cooperation, view to easing or avoiding a potentially significant negative impact on the environment prior to approval of such a plan or program.

Ukraine has borders with seven countries, 19 of the 27 administrative and territorial units are borderline. In the border areas such as Vinnytsia, Volyn, Ivano-Frankivsk, Lviv, Luhansk, Odessa, Sumy, Kharkiv, Chernivtsi, Chernihiv, Donetsk, nine European regions Bug, Upper Prut, Dniester, Dnieper, Carpathian, Lower Danube, Slobozhanshchina, Donbass and Yaroslavna are created, five European regions are created with states - EU members (Poland, Slovakia, Romania, Hungary). Within the European regions crossborder cooperation has been since 1993 .

According to the State program of development of cross-border cooperation 20162020 years, approved by the Cabinet of Ministers of Ukraine on August 23, 2016, No. 554 among the main priorities of Ukraine there is to strengthen the cross-border cooperation in the field of ecology, integrity and continuity of the ecological network to create a warning system for trans-boundary movement air pollutants and rivers, minimize negative effects on the environment, conservation of biological and landscape diversity, sustainable use, protection and restoration of water resources, the creation and functioning of trans-boundary protected areas and facilities with the need to preserve the integrity and continuity of ecosystems, natural corridors, ecological networks formation based on the basin principles of the nature.

The Dnieper river is one of the largest rivers of Europe, the swimming pool of which is 511 thousand $\mathrm{km}^{2}$ and is located within three states - the Russian Federation (19.8\% of the total area of the pool), Belarus (22.9\%), and Ukraine (57.3\%). Cross-border Dnieper basin is a diversified complex that has a high natural and socio-economic value to the three neighboring countries, but the environmental crisis, caused by the construction on the Dnieper cascade reservoirs that completely changed the dynamics of flow, extensive sys- tem management, large-scale land reclamation, construction within the basin of the industrial complex, vast amounts of water for industrial and agricultural production, dumping large amounts of contaminated water, etc. [4-8], led to a significant deterioration in the functioning of integrity of geo-hydroeco-system of the trans-boundary basin, and quality of drinking water and as a result, led to deteriorating the health of people. Because of historical patterns of development of the Ukrainian part of the Dnieper river basin in its territory there is more than $60 \%$ of total industrial production in Ukraine. The area of arable land in trans-boundary basin is 283 thousand $\mathrm{km}^{2}$, or $55.4 \%$ of the total area of the basin, of which 206 thousand $\mathrm{km}^{2}$ (72.8\%) are in Ukraine. About half the state's population resides in the territory of the basin and two thirds of drink water is from the Dnieper. Therefore, taking into account the conditions of high anthropogenic load for the rational management of natural resources the search for optimal interaction between management, man and nature is necessary, i.e. the formation of balanced relations between the exploitation geo-hydro-ecosystem their guard and purposeful transformation [9, 10]. Taking into account the socio-economic situation of cross-border the environmental situation in the Dnieper basin is constantly unstable [11]. Therefore, to solve the environmental problems of trans-boundary river, the most promising is a practical evidence-based implementation of basin principle of nature, which involves the use of an integrated approach to land and water conservation measures on the basis of the systematic research. The main stage in the territorial organization of transboundary basin environmental management is to determine the spatial and temporal patterns of processes of degradation of the complex as a whole and determine specific relationships to research chain «environmental sustainability or breach of landscapes - the quality of surface water - human health» conditions for sustainable operation of the natural geohydro-ecosystem Dnieper basin, meeting the needs of the population and production of natural resources with minimal disturbances 
of geo-environment of natural integrity and improving the nation's health. Geo-planning of the territory of trans-boundary river basin should be based on assessment of agro genic transformation of structural and functional state of landscape ecosystems as the main violator of integrity geo-hydro-eco-system and environmental problems of the Dnieper river basin. The results are aimed at solving a number of topical issues and problems implementing the Water Framework Directive 2000/60 /EU in Ukraine, the Water Strategy of Ukraine till 2025, Directive 2001/42 /EU and the Law of Ukraine «On Strategic Environmental Assessment», the Law of Ukraine «On Approving the National Target Program Development of Water and Environmental Rehabilitation of the Dnieper river for the period till 2021».

The basis of the research objectives is entrusted with the implementation of strategic environmental assessment of space-time transformation of landscape of the eco-systems of the Dnieper river catchment area on the basis of river basin approach.

L.M. Korytnyy [12] estimates the drainage basin as a «special spatial unit of the biosphere, the most promising for the study of multidimensional nature, economy and environmental management». The advantages of using the basin approach for environmental research and the organization of environmental management indicates the clarity and simplicity of selection borders; hierarchical structure that allows you to jump to different territorial levels of government; organization unidirectional flows of matter, energy and information; geo-system relationship that enables to carry out all types of environmental monitoring; restriction of soil and vegetation, settlement system and environmental management to individual basin structures; localization anthropogenic sources of pollution along watercourses watershed.

\section{RESEARCH MATERIALS AND METHODS}

To separate annual sub-basin of the Dnieper river into groups depending on the order of the main channel, the approach of Stralera-Filosofova used [12, 13]. The ability to study geomorphological features of the load on the Dnieper basin and all components of the landscape in relation to the characteristics of water flow parameters allows the basin organization area at watersheds erosion forms of IV procedure, which provides for the identification of landscape heterogeneity territory.

Agricultural development and distribution of forest area in the basin of the Dnieper river is determined based on decoding of the data of the land remote sensing (LRS) using correctly calibrated series of MODIS satellite images (geometric distinction $\sim 230 \times 230 \mathrm{~m}$ ) as of 23.04.2015 and 13.08.2015. Thematic image interpretation procedures conducted on the basis of dimensionless index NDVI normalized differential vegetation index. The official statistics were used for the purpose of comparison and correction of the results.

To investigate the erosion potential of landscapes different-order catchment of river sub-basin by morphometric characteristics of the terrain (part of slopes is more than $1^{\circ}$, Part of the southern slopes, the proportion of cultivated slopes) using the working module Surface of Spatial Analyst Tools and Zonal Statistics of Spatial Analyst Tools.

Earlier a systematic approach was presented, using cluster analysis, multi-functional GIS-instruments and LRS data to analyze anthropogenic load capacity and display of water-erosion processes in agricultural landscapes in the territory of the regional geoeco-system. Reproduced approach is used in part for grouping different-order watershed sub-basin of the Dnieper river as to agricultural development and environmental condition. Spatial clustering was carried out on six indicators to assess agrogenic transformation of structural and functional state of landscape ecosystems Dnieper river basin: forest cover, plowing, squares slopes more $1^{\circ}$, squares slopes of southern exposure, the area cultivated slopes, eroded areas of arable land. For this tool we used Grouping analysis of Spatial Statistics Tools. For processing, GIS analysis and mathematical modeling spatial heterogeneity of distribution of the studied parameters we used licensed software ArcGIS 
10.1, MathWorks MATLAB 7.9 R2009b and STATISTICA Advanced + QC for Windows v.10 Ru.

\section{RESULTS AND DISCUSSION}

As a result of spatial hydrological gemodelling, it has been found that almost half the length of all the erosion forms of the Dnieper river basin is forms of 1 st order, and $90 \%$ of the total length is 1-4 orders of magnitude. For all the basin of the Dnieper $(\mathrm{S}=511$ thousand $\mathrm{km}^{2}$ ) we identified 776 pools ranging from 1.9 to $22.680 .2 \mathrm{~km}^{2}$ IV-IX orders. The analysis of the catchment area of differentorder Dnieper basin showed that the area is drained by thalwegs from the first to the fourth order that makes $58.4 \%$, fifth and sixth order $-33 \%$, from the seventh to ninth $8.6 \%$, so the main supply bed sediments is carried by the top and middle managers $(91.4 \%)$ and local power drifts lower level bed of the Dnieper is $1.8 \%$. The main power source is snow waters in the upper reaches, they constitute about $50 \%$, ground $-27 \%$ and rain more than $23 \%$ [14, 15].

Woods, as part of the natural areas of the Dnieper basin perform a number of important and unique ecological and economic functions. They affect the water exchange and the state of aquatic ecosystems, prevent soil erosion, prevent from the formation of gullies and landslides, as well as landscapes and preserve the fertility of grants and so on. Degree of river sub-basin watershed forest preserves the natural ecological balance of the entire trans-boundary basin, which is significantly disrupted by human activities. Land resources of the Dnieper river basin are characterized by a high level of business development. When taking into account the degree of tillage and forest to assess the consequences of the anthropogenic violation of the territory [16] transfer from medium to strong degree of transformation of land resources is associated with a share of more than $40 \%$ of arable land and forest cover at least $20 \%$. The analysis of the impact of the main components of the agro-landscape on the formation of maximum slope runoff losses showed [17] that the largest order in the functioning of agro-land- scape systems is observed in $40-60 \%$ of tillage and field protection forest cover of $17-20 \%$. The smallest loss of river flow is observed in the weighted average slopes to $2.5^{\circ}$, when plowing watershed is $40-60 \%$, natural grasslands $-33-53 \%$ forest cover and shelter $7 \%$ [18].

Forest resources are very unevenly distributed throughout the basin of the Dnieper River. Forests are mainly concentrated in the upper part of the basin and are underrepresented in its lower part, dominated by a relatively small area of artificial afforestation and forest shelter belts. The total forest area is approximately $175.4 \mathrm{~km}^{2}$ (Fig. 1a), including Belarus - 48.6\%, Russian Federation $31.6 \%$ and Ukraine $-17.1 \%$. Forest cover of trans-boundary Dnieper basin for individual catchment river sub-basin ranges from $0 \%$ to 95\% (Fig. 1b): Most of sub-basin ( 97\%) of forestation $>20 \%$ are located in the boundaries of the upper reaches (forest area) of the Dnieper river in its all sub-basin in the steppe and forest steppe zones of the Dnieper basin forest area is missing two or three times less than the optimum level.

Land resources of the Dnieper river basin are characterized by a high level of development of economic (Fig. 2a). Almost three-fifths of the basin were completely lost its natural landscape as a result of intensive economic use. M.I. Lopyrev [19] proposes to assess the sustainability of agricultural landscapes on parity «arable land / natural lands». On average for gently hilly terrain ratio «arable land / natural lands» defines the following types of state agricultural landscapes: 70:30 - destruction, 60:40 - not stable, 50:50 - boundary stable, 40:60 - minimally stable, 35:65 average stable, 30:70 - resistant, 25:75 - coverings, 0:25: 100-75 - ecological balance with steady increase soil fertility.

Based on this classification, the average value of ecosystem sustainability of landscape in the Dnieper river catchment is estimated as unstable. Plow areas of trans-boundary of the Dnieper river basin in separate sub-basin catchment is distributed evenly enough (Fig. 2b) in the direction of the Dnieper river from north to south, it increases on average 
by $75 \%$, from east to west by $60 \%$. The ratio of arable and forest cover gives an idea of the system of strategic environmental as-

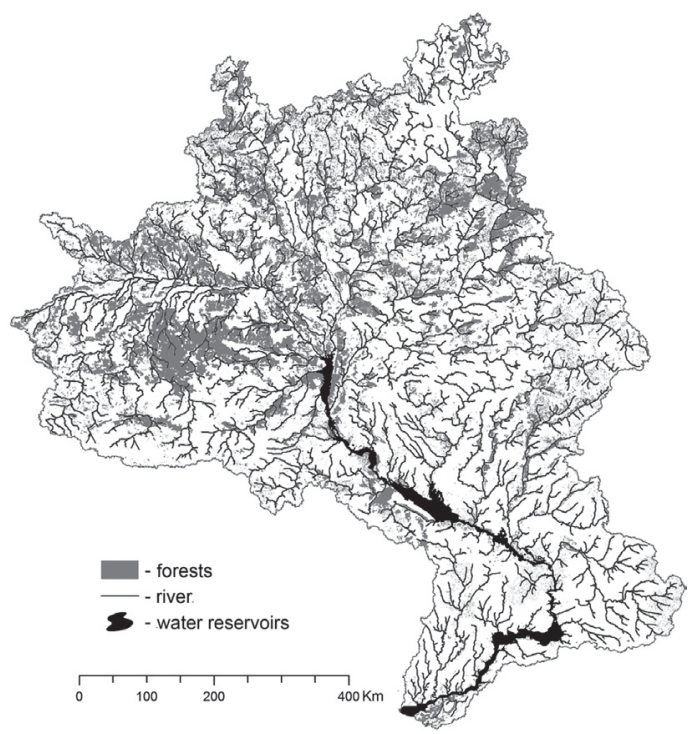

a) sessment of the degree of environmental sustainability as each sub-basin and the entire basin.

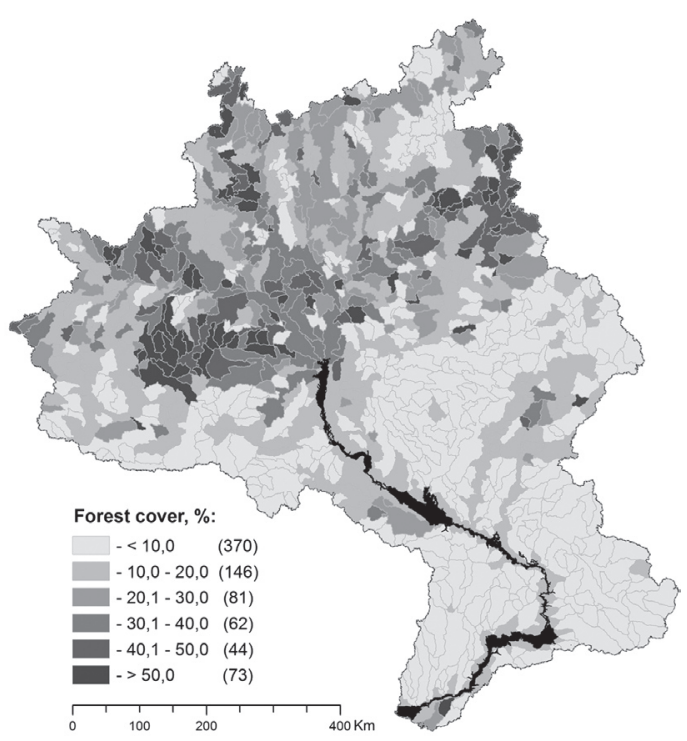

b)

Fig. 1. Spatial characteristics of forest area distribution in the basin of the Dnieper river: $a$ ) forests; $b$ ) share of sub-basin watershed boundaries different-order, $\%$

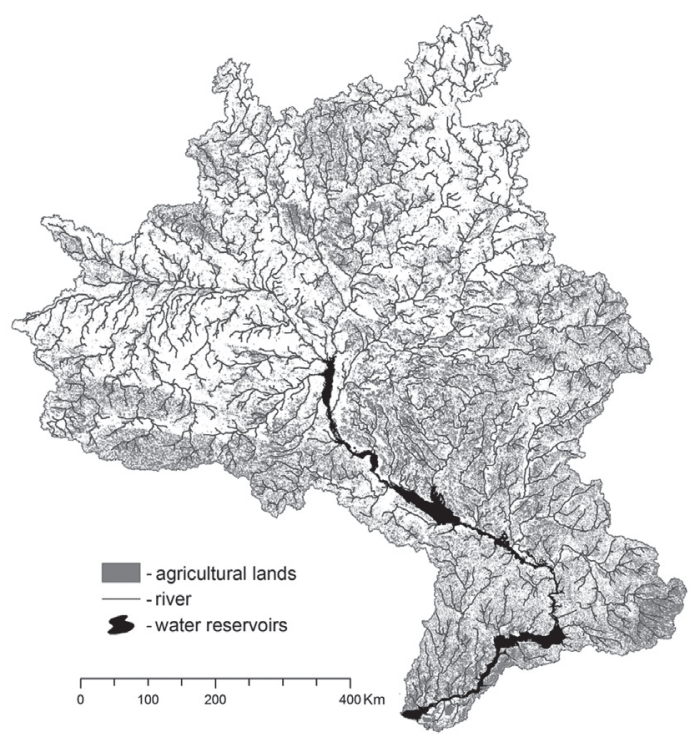

a)

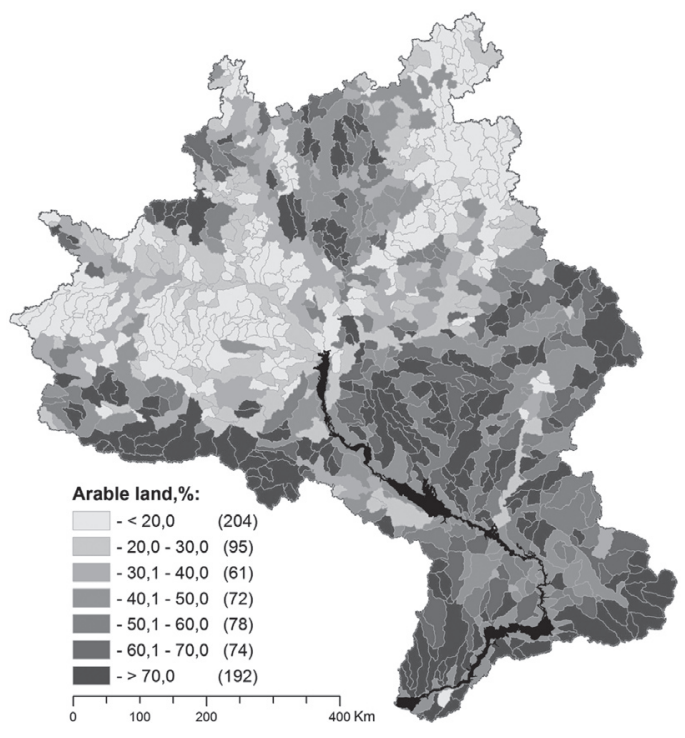

b)

Fig. 2. Agricultural development of landscape in the Dnieper river basin: $a$ ) agricultural lands; $b$ ) share of sub-basin watershed boundaries of different-order \% 
The results of modeling indicate a high degree of environmental vulnerability and displays strong degraded land resources processes more than $70 \%$ of the trans-boundary basin, leading to a significant disruption of hydro-eco-system of the Dnieper River.

The most valuable in the economic terms on which degraded water and erosion have the least impact on agricultural landscapes are upland areas. In the areas of slopes significant signs of erosion processes are primarily caused by anthropogenic factor. Analysis of the situation of erosion suggests that it appears since the slopes 10 [20]. As a result of spatial analysis of the morphometric characteristics of relief we determined that slopes share of the boundaries of the Dnieper river basin (Fig. 3a) in average increases from west to east in 2.7 times, in the direction of the river (north $\rightarrow$ south) distribution is uneven with sinusoidal changes.

A part of the area of slopes of the southern exposure $\mathrm{P}_{\mathrm{sc}}$ is an additional criterion and displays a tendency to exercise pools erosion during snowmelt. $\mathrm{P}_{\mathrm{sc}}$ Criterion for each basin was calculated based on the digital elevation model (DEM) division raster displays, sampling azimuth values ranging from 135 to $225^{\circ}$. It is assumed if the $\mathrm{P}_{\mathrm{sc}}>25 \%$, the basin topography is characterized by high erosion potential during snowmelt [18]. A part of $\mathrm{P}_{\mathrm{sc}}$ is less than $20 \%$ (Fig. 3b) with 183 (23.9\%) sub-basin with a total area of 104.4 thousand $\mathrm{km}^{2} \sim(20.4 \%)$ in the range of $20-25 \%$ with $472(61.6 \%)$ sub-basin area $~ 341.6$ thousand $\mathrm{km} \sim(66.9 \%)$, increased erosion potential in snowmelt are 121 sub-basin watershed with a total area of $\sim 65.0$ thousand $\mathrm{km}^{2}$ (12.7\%).

In the cultivated slopes of the trans-boundary basin the modern water-erosion processes occur mostly in the form of planar flushing. Natural factors of development and intensity of flow are features of topography (slope length and slope exposition), weather conditions (amount and intensity of rain and snowmelt rate), erosion and other soil properties. Plow slopes of the Dnieper river basin in some areas of sub-basins reaches $64 \%$ (Fig. 4a), thus 596 (77.8\%) of the

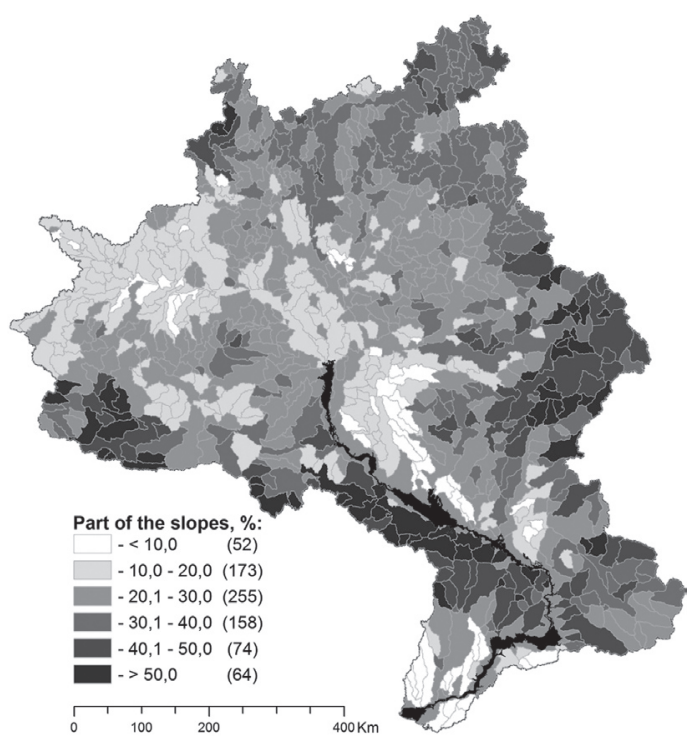

a)

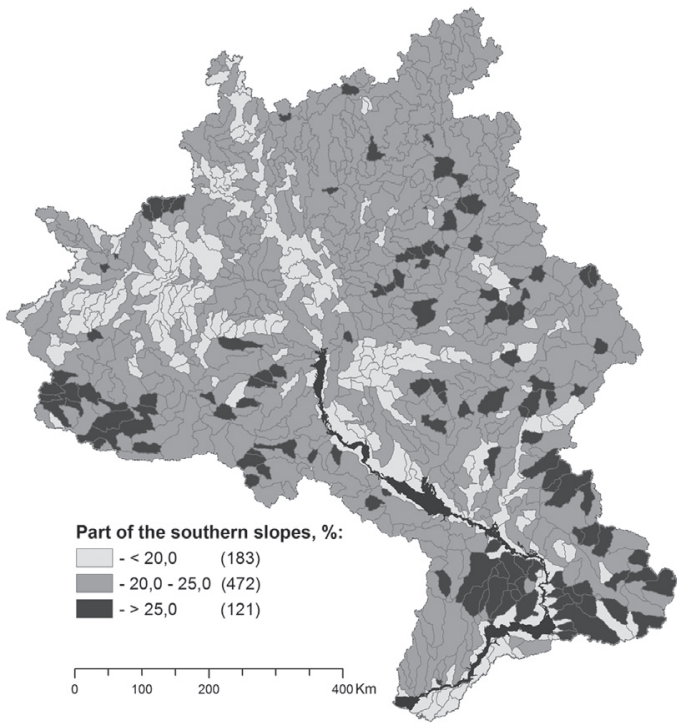

b)

Fig. 3. Characteristics of morphometric parameters of slopes within the boundaries of different-order watershed sub-basin of the Dnieper river: $a$ ) part of the slopes more $1^{\circ}, \% ; b$ ) part of the southern slopes, $\%$ 
sub-basin watershed with the total area of 383.6 thousand $\mathrm{km}^{2}(75.2 \%)$ have less than $20 \%$ of cultivated slopes; 20 to $50 \%$ of cultivated slopes $-174(34.0 \%)$ with the area of 125.1 thousand $\mathrm{km}^{2}(24.5 \%)$, more than $50 \%$ of the slopes are cultivated $6(0.8 \%)$ with an area of 2.3 thousand $\mathrm{km}^{2}(0.5 \%)$. Plow slopes significantly increases (11 times) from west to east trans-boundary basin, and this trend is observed from its source to the delta of the Dnieper, in the direction of plowing slopes of sub-basin landscape increases by an average 4-5 times.

As a result of excessive agricultural development of landscape in the Dnieper river basin, including high tillage, extensive use of productive land, processes of soil degradation, characterized by erosion index, become widespread. It is an indicator of negative changes in the properties of soils in consequence of the processes of water and wind erosion in the territory of agro-landscapes watersheds that lead to the loss of the most fertile soil, removal of humus (degumufication) and nutrients, a significant deterioration in the physical properties of the soil, reducing yield and quality crops. With the deterioration agrophysical properties, susceptibility to erosion which can lead to complete loss of humus horizon and irreversible deterioration of soil increases more. In the medium and strongly washedoff lands opportunity of soil infiltration is reduced to $30 \%$ and washing-off increases 1.5-2.0 times, which leads to a significant increase in accumulation processes in rivers of products erosive destruction of soil with it agrochemicals mio-genes, heavy metals, including radionuclides, which significantly impair the quality of river water, cause eutrophication of water bodies, sedimentation ponds, reservoirs, valleys of small rivers that cause extinction of many of them in the borders of the Dnieper river basin.

According to the historical and geographical research and decryption of satellite images it has been found that over the past 200 years, the total length of small rivers $(100 \mathrm{~km})$ has decreased by almost $40 \%$ with an average speed of degradation of streams almost $15 \mathrm{~km} /$ year. Large-scale extinction of wa-

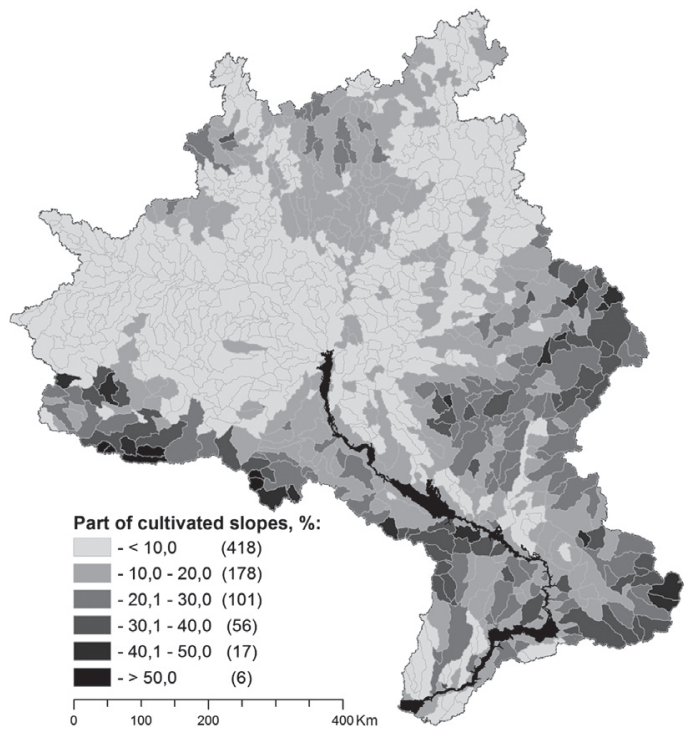

a)

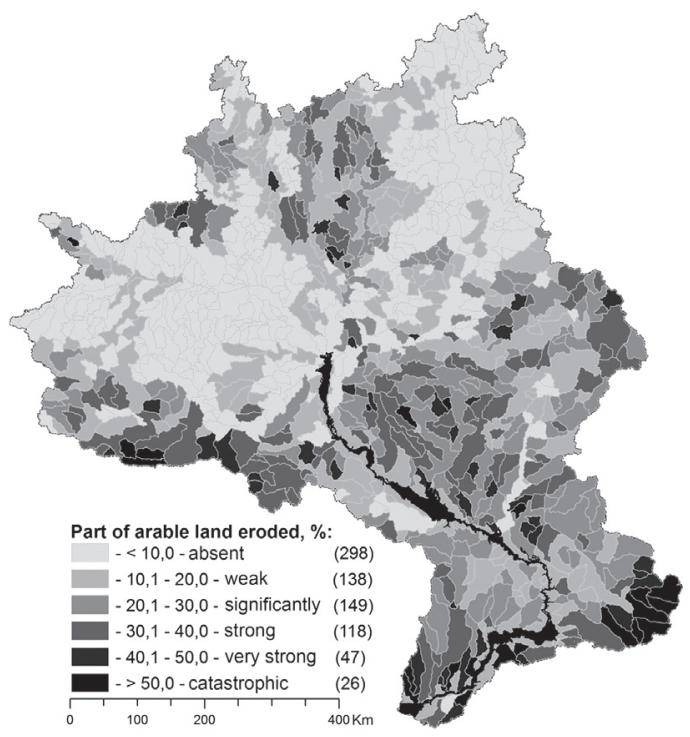

b)

Fig. 4. Erosion danger and intensity of degradation of farmland in the watershed boundaries of different-order in the Dnieper river sub-basin: $a$ ) part of cultivated slopes, $\% ; b$ ) part of arable land eroded, $\%$ 
tercourses lower orders within $85 \%$ of the total length and reduce annual network eutrophication of watercourses $\mathrm{IV}-\mathrm{V}$ orders with shorter overall length of more than $13 \%$, constantly intensified erosion manifestations of human nature. The combination of certain environmental factors creates conditions for the exercise of accelerated erosion and unsustainable economic activity is the main cause of its development, leading to significant degradation of soil and groundwater, and in some cases, possible changes in topography and the boundaries of trans-boundary Dnieper river basin.

Erodibility of soils in the Dnieper basin varies boundaries (Fig. 4b) of $0.13 \%$ (absent) to $74.5 \%$ (catastrophic): 436 ( 56.2\%) catchment of river basins with a total area $\sim 260.2$ thousand $\mathrm{km}^{2}$ (almost $51 \%$ of the total area of the Dnieper basin) have weak or non-existent area of eroded lands; a significant degree of soil erosion with $149(\sim 19.2 \%)$ sub-basin with a total area of $\sim 117.5$ thousand $\mathrm{km}^{2}$ $(\sim 23.0 \%)$; from severe to catastrophic erosion of soil with 191 ( 24.6\%) sub-basin with a total area of $\sim 133.3$ thousand $\mathrm{km} 2(\sim 26.0 \%)$. It is estimated that on average soils slightly eroded shortfall crop is $10-20 \%$, the average eroded $-40-60 \%$ and strongly eroded - up to $80 \%$ [21].

In the steppe and forest steppe zones of the Dnieper basin crop shortfall on eroded soils much depends on the degree of wetting soil, which from the source to the mouth of the Dnieper 3 times reduces. Therefore, for effective agricultural practices and land users to obtain high yields in the steppe and forest steppe zones of trans-boundary basin hydraulic networks were built with a total area of irrigation -2.64 million ha [22], of which $95.5 \%$ is in the territory of Ukraine. Since the beginning of irrigated melioration, changes in operating conditions of all components of the environment have been changed, in particular the direction and speed of groundwater processes. The results of these changes can have a positive effect (moisture improvement, productivity, etc.), and ecologically negative consequences (processes flooding, salinity, alkalinity, water logging). The direction and intensity of negative effects on agricultural and adjacent land depends primarily on the climatic and hydrological conditions of the region, the volume of supply of irrigated water. Culture of the agriculture, state and efficiency of hydraulic networks and use of irrigation water, the processes of degradation and stability of agricultural landscapes in irrigated areas to a greater extent is determined by the level of occurrence of groundwater as the main indicator of hydrogeology-ameliorative condition of irrigated lands and the effectiveness of the collector-drainage [23]. On irrigated land, while maintaining the traditional paradigm of irrigation leads to the increased power humus horizon (for low humus soil is particularly dangerous) and increase the driving force of the process of leaching, transfer of organic matter into the lower profile remote plants soil horizons and, consequently, decrease the efficiency of farming, deterioration of groundwater and topsoil fertility, primarily light and medium grain size. Therefore irrigated agricultural landscapes of the Dnieper basin instead of the standard paradigm of irrigation, the use of which results in the whole world should recognize the poor required a sharp reduction of water consumption [24], reducing water seepage inside the regime, especially through the soil, reduce water losses, reducing irrigation degradation soils. The current stabilization of geo-chemical barriers is in the soil and aeration zone [25]. This gives an opportunity to overcome the impulse internal-soil continualdiscrete paradigm of irrigation and moistening the soil suitable way [26]. Alongside with that to restore the lost fertility of eroded soils you should greatly fertilize especially organic fertilizers. In order to compensate for losses of humus due to erosion, the soil should get 3 times more organic matter than it was washed away because not more than $25-30 \%$ of manure introduced into the soil is humified, but taking into account the constantly increasing cost of fertilizers leads to a permanent negative consequences of erosion in agricultural areas of the Dnieper river basin.

Summary results of the evaluation indicators of the degree of transformation agrogenic 
Table 1

\section{Average different-order sub-basin watershed by the gradation of indicators of the agrogenic transformation of the structural and functional status of landscape ecosystems of the Dnieper river basin}

\begin{tabular}{|c|c|c|c|c|c|c|c|c|}
\hline \multirow{2}{*}{\multicolumn{2}{|c|}{ Indicators }} & \multicolumn{6}{|c|}{ Share in the sub-basin watershed boundaries, \% } & \multirow{3}{*}{$\begin{array}{c}\begin{array}{c}\text { Total, } \\
\mathrm{km}^{2}\end{array} \\
511000\end{array}$} \\
\hline & & \multirow{2}{*}{$\begin{array}{c}<10 \\
198792.70\end{array}$} & \multirow{2}{*}{$\begin{array}{c}10-20 \\
125631.10\end{array}$} & \multirow{2}{*}{$\begin{array}{c}20-30 \\
59463.70\end{array}$} & \multirow{2}{*}{$\begin{array}{c}30-40 \\
50640.40\end{array}$} & \multirow{2}{*}{\begin{tabular}{c|}
$40-50$ \\
31467.00
\end{tabular}} & \multirow{2}{*}{$\begin{array}{c}>50 \\
45005.10\end{array}$} & \\
\hline Forest cover & $\mathrm{S}$ & & & & & & & \\
\hline & $\%$ & 38.9 & 24.6 & 11.6 & 9.9 & 6.2 & 8.8 & 100 \\
\hline \multirow[t]{2}{*}{ Arable land } & $\mathrm{S}$ & 40865.20 & 57972.20 & 66104.70 & 38574.20 & 93048.60 & 214435.10 & 511000 \\
\hline & $\%$ & 8.0 & 11.3 & 12.9 & 7.5 & 18.2 & 42.0 & 100 \\
\hline \multirow{2}{*}{$\begin{array}{l}\text { Slopes } \\
\text { more } 1^{\circ}\end{array}$} & $\mathrm{S}$ & 16612.51 & 92872.06 & 176890.40 & 134982.50 & 48567.10 & 41075.44 & 511000 \\
\hline & $\%$ & 3.3 & 18.2 & 34.6 & 26.4 & 9.5 & 8.0 & 100 \\
\hline \multirow{2}{*}{$\begin{array}{l}\text { Cultivated } \\
\text { slopes }\end{array}$} & $\mathrm{S}$ & 223917.60 & 159686.10 & 77119.09 & 38679.22 & 9297.20 & 2300.80 & 511000 \\
\hline & $\%$ & 43.8 & 31.2 & 15.1 & 7.6 & 1.8 & 0.5 & 100 \\
\hline \multirow{2}{*}{$\begin{array}{l}\text { Arable land } \\
\text { eroded }\end{array}$} & $\mathrm{S}$ & 151620.30 & 108608.20 & 117436.60 & 88332.11 & 29523.40 & 15479.40 & 511000 \\
\hline & $\%$ & 29.7 & 21.3 & 23.0 & 17.3 & 5.8 & 3.0 & 100 \\
\hline
\end{tabular}

structural and functional status of landscape ecosystems of the Dnieper river basin are shown in Table 1.

As a result of geo-modeling (spatial grouping or clustering) typing was made (Fig. 5) of watershed sub-basin by six indicators of the agrogenic transformation of structural and functional state of the landscape ecosystems of the Dnieper river basin. There are three groups (clusters), where defining classification signs were forestry, erodibility and tillage (including slopes) soil (Table 2), this section is consistent with the physical and geographic zone trans-boundary Dnieper river basin and the degree of anthropogenic load, sub-basin of Group I confined to the forest zone, II and III groups to steppe and steppe zones. Tillage and soil erosion gives an idea of the results of large-scale long agrogenic load and modern structural and functional status of landscape ecosystems in the Dnieper river basin.

Group I (landscape and ecologically stable or slightly broken) - sub-basin of absent or weak soil erodibility and low agrogenic transformation, where the propor- tion of arable land is on average about 19\%, including the slopes of $5 \%$, average forest cover of about $30 \%$. This group is $95 \%$ gone

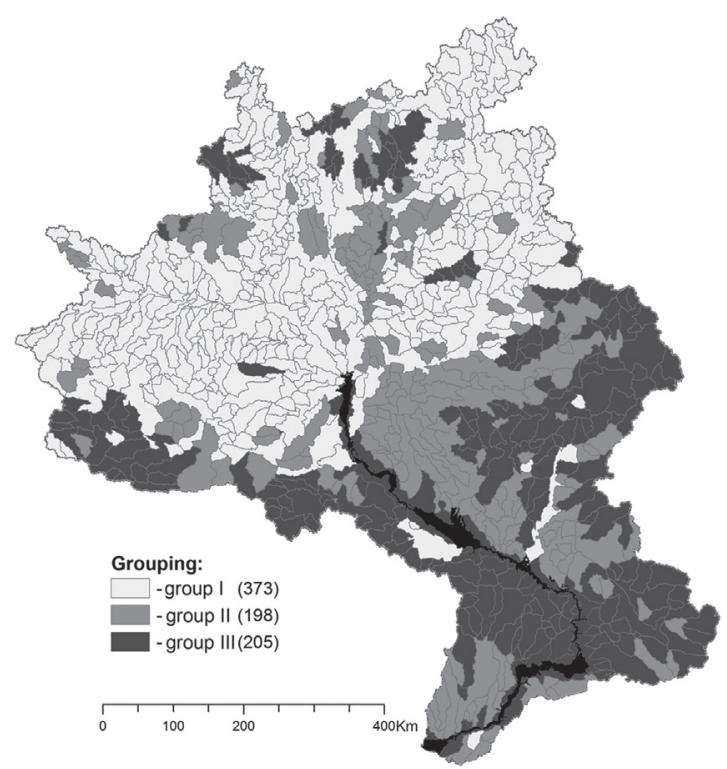

Fig. 5. Spatial group of the Dnieper basin by the level of the agrogenic transformation of structural and functional state of landscape ecosystems 
Table 2

Indicators of agricultural development and ecological status of catchment sub-basin trans-boundary Dnieper basin

\begin{tabular}{c|cc|c|c|c|c}
\hline \multirow{2}{*}{ Group } & $\begin{array}{c}\text { Part of arable } \\
\text { land }\end{array}$ & $\begin{array}{c}\text { Part of forest } \\
\text { cover }\end{array}$ & $\begin{array}{c}\text { Part of arable } \\
\text { land eroded }\end{array}$ & $\begin{array}{c}\text { Part of slopes } \\
\text { more 1 }\end{array}$ & $\begin{array}{c}\text { Part } \\
\text { of cultivated } \\
\text { slopes }\end{array}$ & $\begin{array}{c}\text { Part } \\
\text { of southern } \\
\text { slopes }\end{array}$ \\
\cline { 2 - 7 } & \multicolumn{6}{|c}{$\%$} \\
\hline \hline I & $19.3 \pm 8.7$ & $29.8 \pm 11.5$ & $5.8 \pm 4.3$ & $26.4 \pm 8.9$ & $5.0 \pm 3.8$ & $21.3 \pm 2.2$ \\
II & $75.7 \pm 15.1$ & $6.9 \pm 4.4$ & $33.2 \pm 11.4$ & $16.6 \pm 8.0$ & $12.1 \pm 6.3$ & $20.9 \pm 2.8$ \\
III & $66.7 \pm 11.2$ & $7.4 \pm 4.8$ & $28.5 \pm 11.0$ & $44.0 \pm 13.2$ & $28.2 \pm 10.1$ & $24.9 \pm 2.8$ \\
\hline
\end{tabular}

catchment area of the rivers located in the upper reaches of the river, the total number was $373(48.7 \%)$ sub-basin with a total area of 224.2 thousand $\mathrm{km}^{2}(\sim 439 \%)$.

Group II (high agro-genic transformation of landscapes) - sub-basin with high agricultural development (about 76\%), a significant and strong low erodibility and forestation $\sim 7 \%$. It includes $198(\sim 25.8 \%)$ sub-basin with a total area of 116.6 thousand $\mathrm{km}^{2}$ ( 22.8\%).

Group III (agrogenic transformed with high soil erosion risk) - sub-basin with high agricultural development (about 67\%), strong

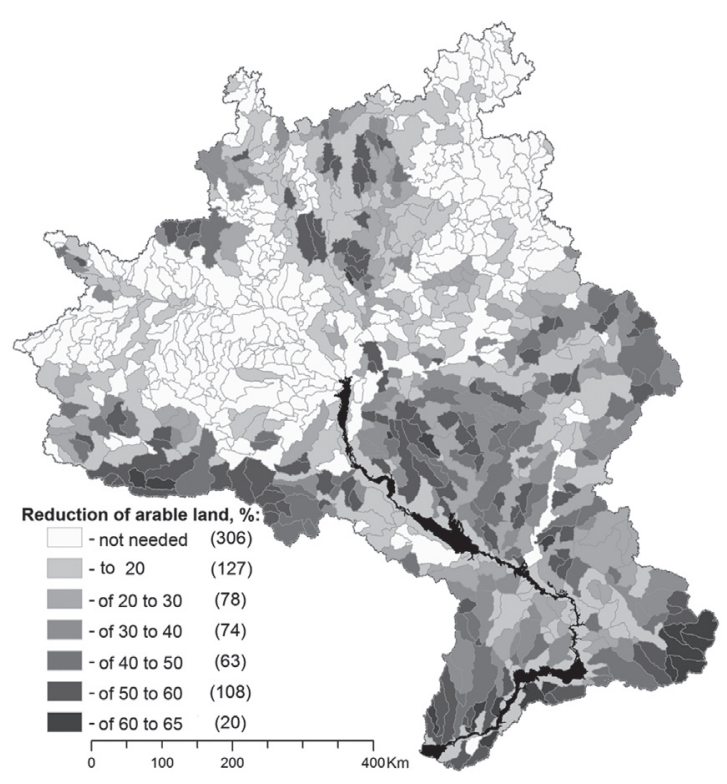

Fig. 6. Need to reduce agricultural burden on the Dnieper river basin and very strong erodibility, low forestation $\sim 7 \%$, a high proportion of cultivated slopes an average of $44 \%$ and increased erosion potential during snowmelt.

Construction of the cascade on the Dnieper of six reservoirs with a total area of $6950 \mathrm{~km}^{2}$ and total accumulated volume of $43.8 \mathrm{~km}^{3}$ of water led to the flooding of 50 thousand $\mathrm{km}^{2}$ and flooding of 10 thousand $\mathrm{km}^{2}$ of productive land violated the ecological balance and radically altered water exchange conditions compared to natural conditions it slowed to 30 times [27]. Taking into account these conditions the waterfront of the Dnieper basin of IX procedure was confined to the third degree of agrogenic transformation of the structural and functional status of landscape ecosystems. It includes 205 $(\sim 26.8 \%)$ sub-basin with a total area of 170.2 thousand $\mathrm{km}^{2}(\sim 33.3 \%)$.

In most sub-basin of the river Dnieper main criterion of destabilization of agricultural landscapes is a high level of tillage, in this case the most effective tool for improving the ecological balance of the territory trans-boundary basin study is the reduction of arable land for other land or environmental fund. As a result of the calculations it is necessary to reduce the arable land, especially in the territories agrogenic transformed sub-basins with high soil erosion hazard, the need for reducing the extent of extensive farming agro-landscape load on the Dnieper river basin was identified (Fig. 6) the boundaries of $470(61.4 \%)$ of the sub-basin 
with the total area of $\sim 346.3$ thousand $\mathrm{km}^{2}$ $(\sim 67.8 \%)$.

As the arable lands are the main source of agricultural production and guarantee food security in the Dnieper river basin it is necessary to find a compromise between achieving the environmental sustainability of agricultural landscapes and cost-effective intensity of agricultural production, especially organic farming to obtain stable yields and reduce the level of pollution of surface waters.

\section{CONCLUSIONS}

Strategic environmental assessment and spatial clustering was carried out on six indicators of agrogenic transformation of structural and functional state of landscape ecosystems of the Dnieper river basin: forest cover, plowing, squares slopes more $1^{\circ}$, squares slopes of southern exposure, the area cultivated slopes, eroded areas of arable land. Forest of watershed river sub-basin ranges from $0 \%$ to $95 \%$, approximately $67.4 \%$ subbasin steppe and steppe zones with a total area of $\sim 324.4$ thousand $\mathrm{km}^{2}(63.5 \%)$ have less than $20 \%$ forests, indicating a low capacity preserving the natural ecological balance in areas of the middle and lower reaches of the Dnieper river. Much of the basin completely lost its natural landscape as a result of intensive economic use. About 416 watershed subbasins, occupying $60.2 \%$ of the Dnieper basin have a strong degree of transformation of the land. The analysis of the degree of forest and arable indicate high ecological vulnerability and displays strong degraded land resources processes more than $70 \%$ of the trans-boundary basin, leading to a significant disruption of hydro-eco-system Dnieper river. Erosion and potential cumulative watershed sub-basin depends on the presence of particles agro-landscapes slopes more $1^{\circ}$. Erosion and cumulative potential of watershed sub-basin depends on the presence of particles agro-landscapes slopes more $1^{\circ}$. About $72 \%$ of watershed subbasin with more than $20 \%$ of landscapes is on the slopes. Almost 12.7\% (65.0 thousand $\mathrm{km}^{2}$ ) area of the Dnieper basin has increased at erosional potential snowmelt. Plow slopes of the Dnieper river basin sub-basin in some areas reaches 64\%, including 180 (23.5\%) sub-basin with a total area of 127.4 thousand $\mathrm{km}^{2}$ (25.0\%) have a part of plowed slopes of more than $20 \%$. Their number increases significantly (11 times) from west to east of the trans-boundary basin, and this tendency of the agrogenic violation of agricultural landscapes is observed from the source to the delta of the Dnieper, in the direction of plowing slopes in the sub-basin boundaries increases on average $-4-5$ times. The results of the excessive agricultural development of the landscape of the Dnieper basin led to a significant intensification of soil degradation processes, characterized by the erosion indicator that constantly accompanied by water and wind erosion. This leads to a significant reduction in infiltration of the opportunity and increasing washing-off the soil in 1.5-2.0 times and a significant increase in accumulation processes in rivers the products of erosive destruction of soil, and alongside with that agrochemicals, myogenes, heavy metals, including radionuclides that significantly worsen the quality of the river water, cause eutrophication of water bodies, sedimentation ponds, reservoirs, valleys of small rivers that cause extinction of many of them in the borders of the Dnieper river basin. From medium to catastrophic soil erosion degree with 340 ( $\sim 4.4 \%$ ) of sub-basins with the total area of 250.8 thousand $\mathrm{km}^{2}(\sim 49.0 \%)$, which is the reason for the shortfall in yield from $40 \%$ to $80 \%$.

As a result, strategic environmental assessment and geo-modeling determined that more than $50 \%$ of the Dnieper basin has high agrogenic transformation of the structural and functional status of the landscape ecosystems. The main criterion for the destabilization of agricultural landscapes is a high level of tillage, in this case the most effective tool for improving the ecological balance of the territory of the trans-boundary basin study is the reduction of arable land for other land or environmental fund 470 sub-basin boundaries with a total area of $\sim 346.3$ thousand $\mathrm{km}^{2}$ ( 67.8).

Rational land use in accordance with the strategic environmental assessment should 
take into account the characteristics and features of the landscape, promote the protection and reproduction of soil, vegetation and other natural components in a single agreement between the countries of trans-boundary basin. This can be achieved through the basin of nature and landscape-ecological approach [28], which involves identifying relationships in ecosystems agricultural landscapes and water bodies, their record in selecting destinations and types of land use in the watershed subbasin boundaries. To generate environmentally sustainable agricultural landscapes and reducing erosion and cumulative processes in catchment areas of river basins priority must provide the following set of measures: organizational and economic reclamation - a system of soil rotation, mosaic structure of land, degraded land, creation of ecological frame area etc. hydro-meliorate - sustainable irrigation, erosion rates, protection zones, bottom buildings, dams, bridges, spray flow etc. land improvement - limiting the use of heavy tillage machinery, creating buffer strips of grasses, soil protecting technologies, reduction of pesticide use, handling across slopes, etc; agroforestry shelter, and stock-regulating and forest belts; continuous afforestation slopes, etc.

\section{ЛIТЕРАТУРА}

1. Палехов Д.О. Правові проблеми імплементації механізму стратегічної екологічної оцінки на Україні / Д.О. Палехов // Наука і освіта 2005: Матер. VIII Міжнар. наук.-практ. конф. - Дніпропетровськ: Наука і освіта. - 2005. - Т. 47. C. 59-61.

2. Чернихівська А.В. Стратегічна екологічна оцінка пріоритетів регіонального розвитку продуктивних сил: дис. ... канд. екон. наук: спец. 08.00.06 «Економіка природокористування та охорони навколишнього середовища» / А.В. Чернихівська. - K., 2011. - 190 c.

3. Хлобистов $C . B$. Інституційні передумови імплементації стратегічної екологічної оцінки: аналіз стану державного планування та прогнозування соціально-економічного розвитку / Є.В. Хлобистов // Вісник Сумського державного університету. - 2005. - № 10 (82). - С. 48-53. - (Серія: Економіка).

4. План управления пилотным речным бассейном верхнего Днепра на территории республики Беларусь и Украины. Компонент А - анализ речного бассейна [Електронний ресурс] / Республиканский центр радиационного контроля и мониторинга окружающей среды (Республика Беларусь); Украинский центр экологических и водных проектов Академии технологических наук (Украина). - 2013. - 103 с. - Режим доступу: http://blacksea-riverbasins.net/system/ files_force/DNIEPER_RBA_final\%20to\%20upload $\% 20 \bar{R} U$ S $\%$ 20FINAL.pdf?download=1

5. Проблема возрождения пойменных водоемов низовий Днепра и пути ее решения / Ю.В. Пилипенко, В.А. Корниенко, А.А. Липисивицкий, О.Э. Довбыш // Зелена економіка: перспективи впровадження в Україні: Матеріали Міжнародної конференції. - К., 2012. - Т. 1. - С. 179-182.

6. Оптимизация антропогенной нагрузки на реки Нижнего Приднепровья / И.А. Шахман, Ю.В. Пилипенко, А.А. Липисивицкий, О.О. Демьянова // Захист навколишнього середовища, енергоощадність, збалансоване природокористування: II Міжнародний конгрес. - Львів, 2012. C. 159 .
7. Комплексная оценка качества воды низовья Днепра / Н.Г. Александрова, Т.Г. Мороз, В.С. Полищук, Є.Я. Россова // Водные ресурсы. - 1985. - № 6. - С. 199-127.

8. Комплексна оцінка екологічного стану басейну Дніпра / В.Д. Романенко [та ін.]. - К.: Інститут гідробіології НАН України, 2000. - 103 с.

9. Бассейновый подход к организации природопользования в Белгородской области: [монография] / Ф.Н. Лисецкий, А.В. Дегтярь, А.Г. Нарожняя и др.; под ред. Ф.Н. Лисецкого. - Белгород: Константа, 2013. - 89 с.

10. Реки и водные объекты Белогорья: [монография] / Ф.Н. Лисецкий, А.В. Дегтярь, Ж.А. Буряк [и др.]; под. ред. Ф.Н. Лисецкого. - Белгород: Константа, 2015. - 362 с.

11. Экологическое состояние бассейна Днепра на территории России / под общей ред. Г.М. Черногаевой, А.С. Зеленова, М.С. Зеленовой, Ю.А. Малеванова. - М.: Метеоагентство Росгидромета, 2009. - 230 c.

12. Корытный Л.М. Бассейновая концепция в природопользовании / Л.М. Корытный. - Иркутск: Изд-во Института географии СО РАН, 2001. $-163 \mathrm{c}$.

13. Симонов Ю.Г. Речной бассейн и бассейновая организация географической оболочки / Ю.Г. Симонов, Т.Ю. Симонова // Эрозия почв и русловые процессы. - М., 2004. - Вып. 14. - С. 7-32.

14. Пічура B.I. Структура гідрогеоморфологічної системи для створення геооснови екологічного каркаса басейну річки Дніпро / B.I. Пічура // Вісник Дніпропетровського державного агроекономічного університету. - 2016. - № 2 (40). - C. 19-25.

15. Пічура B.I. Сільськогосподарське порушення екологічної стійкості басейну річки Дніпро [Електронний ресурс] / В.I. Пічура // Наукові доповіді НУБіП України. - 2016. - № 5 (6). - Режим доступу: http://journals.nubip.edu.ua/index.php/ Dopovidi/article/view/7231/7010

16. Максимович A.M. Оценка уровня антропогенизации территории по изучению растительного покрова / А.М. Максимович, И.М. Леонович, 
Н.В. Ковальчик // Географические аспекты рационального природопользования. - Минск: Наука и техника, 1985. - С. 10-14.

17. Белолипский B.A. Теоретическое обоснование и пути почвоводоохранной оптимизации агроландшафтов в зоне степи Украины: автореф. дис. ... д-ра с.-х. наук / В.А. Белолипский. - К., 2006. $-44 \mathrm{c}$.

18. Буряк Ж.А. Бассейновая организация природопользования в Белгородском экорегионе: автореф. дис. ... канд. геогр. наук / Ж.А. Буряк. - М., 2015. -23 c.

19. Проектирование и внедрение эколого-ландшафтных систем земледелия в сельскохозяйственных предприятиях Воронежской области / М.И. Лопырев, В.Е. Шевченко, Н.И. Зезюков, В.А. Федотов; под общ. ред. М.И. Лопырева. - Воронеж: Истоки, 1999. - 186 с

20. Олійник B.C. Еродованість земель в агроландшафтах Передкарпаття / В.С. Олійник, Н.В. Бєлова // Геополитика и экогеодинамика регионов. - 2014. - Т. 10, Вып. 2. - С. 361-364.

21. Лисеикий Ф.Н. Современные проблемы эрозиоведения / Ф.Н. Лисецкий, А.А. Светличный, С.Г. Черный; под ред. А.А. Светличного. - Белгород: Константа, 2012. - 456 с.

22. Программа экологического оздоровления бассейна Днепра [Електронний ресурс]. - 2007. - 86 с. - Режим доступу: http://projects.inweh. unu.edu/inweh/getdocument.php? $\mathrm{F}=1660666292$ 4baa3e312e 05e2.18745111
23. Пичура В.И. Вековое изменение устойчивости агроландшафтов в зоне оросительных мелиораций сухостепной зоны (на примере юга Херсонской области) / В.И. Пичура, Ф.Н. Лисецкий, Я.В. Павлюк // Научные ведомости Белгородского государственного университета. - 2014. - № 17 (188). - Вып. 28. - С. 140-147. - (Серия: Естественные науки).

24. Воеводина Л.А. Влияние переполивов при капельном орошении на мелиоративное состояние земель / Л.А. Воеводина // Пути повышения эффективности орошаемого земледелия: сб. ст. ФГНУ «РосНИИПМ»; под ред. В.Н. Щедрина. Вып. 45. - Новочеркасск: Геликон, 2011. C. $49-56$.

25. Ion association in water solution of soil and vadose zone of chestnut saline solonetz as a driver of terrestrial carbon sink / A.A. Batukaev, A.P. Endovitsky, A.G. Andreev et al. // Solid Earth. - 2016. - No. 7, Is. 2. - P. 415-423.

26. Управление геохимическими процессами в орошаемых почвах на технологической платформе ноосферы / В.П. Калиниченко, А.П. Ендовицкий, Т.М. Минкина и др. // Природообустройство. - 2014. - № 3. - C. 6-11.

27. Гавриленко О.П. Екогеографія України / О.П. Гавриленко. - К.: Знання, 2008. - 646 с.

28. Крюкова Н.А. Ландшафтно-экологическое обустройство земель: [монография] / Н.А. Крюкова, В.Д. Постолов, О.В. Спесивый. - Воронеж: ФГОУ ВПО Воронежский ГАУ, 2010. - 218 с.

\section{REFERENCES}

1. Palekhov, D.O. (2005). Pravovi problemy implementacii' mehanizmu strategichnoi' ekologichnoi' ocinky na Ukrai'ni [The Legal Problems of Implementing the Mechanism of Strategic Ecological Evaluation in Ukraine]. Science and Education '05: materialy VIII Mizhnarodnoi' naukovo-praktychnoi' konferencii' - the Materials of the 8nd International Scientific Practical Conference. (Vol. 47, pp. 59-61). Dnipropetrovs'k: Nauka i osvita [in Ukrainian].

2. Chernykhivska, A.V. (2011). Strategichna ekologichna ocinka priorytetiv regional'nogo rozvytku produktyvnyh syl [Strategic Ecological Evaluation of the Priorities of the Regional Development of Productive Forces]. Candidate's thesis. Kyiv [in Ukrainian].

3. Khlobystov, Ye.V. (2005). Instytucijni peredumovy implementacii' strategichnoi' ekologichnoi' ocinky: analiz stanu derzhavnogo planuvannja ta prognozuvannja social'no-ekonomichnogo rozvytku [Institutional Premises of Implementing Strategic Ecological Evaluation: the Analysis of the Conditions of the Government Planning and Forecasting of Socio-economic Development]. Visnyk Sums'kogo derzhavnogo universytetu. Serija: Ekonomika - The Bulletin of Sumy State University. Series: Economic, 10 (82), 48-53 [in Ukrainian].

4. Plan upravleniya pilotnym rechnym basseynom verkhnego Dnepra na territorii respubliki Belarus' i Ukrainy. Komponent A - analiz rechnogo basseyna (2013). [The Plan of Managing the Pilot River Basin of the Upper Dnepr on the territory of the
Republic Belarus and Ukraine. The Component A the Analysis of a River Basin]. blacksea-riverbasins. net. Retrieved from http://blacksea-riverbasins. net/system/files_force/DNIEPER_RBA_final $\% 20$ to\%20upload\%20 RUS\%20FINAL.pdf?download=1 [in Russian].

5. Pilipenko, Yu.V., Korniyenko, V.A., Lipisivitskiy, A.A., \& Dovbysh, O.E. (2012). Problema vozrozhdeniya poymennykh vodoemov nizoviy Dnepra i puti ee resheniya [The Problem of Restoring Inundated Water Bodies of the Dnepr lower reaches and the Ways to Solve it]. Green Economics: the Prospects of introducing in Ukraine: Materialy mizhnarodnoi' konferencii' - The Materials of the International Conference. (Vol. 1, pp. 179-182). Kyiv [in Russian].

6. Shakhman, I.A., Pilipenko, Yu.V., Lipisivitskiy, A.A., \& Demyanova, O.O. (2012). Optimizatsiya antropogennoy nagruzki na reki Nizhnego Pridneprov'ya [Optimizing Anthropogenic Load on the Rivers of the Low Pridneprovie]. Environmental Conservation, Energy Efficiency, Sustainable Nature Management: 2-j Mizhnarodnyj kongres - The $2^{\text {nd }}$ International Congress. (pp. 159). Lviv [in Russian].

7. Aleksandrova, N.G., Moroz, T.G., Polishchuk, V.S., \& Rossova, Ye.Ya. (1985). Kompleksnaya otsenka kachestva vody nizov'ya Dnepra [Integrated Evaluation of the Water Quality of the Dnepr Lower Reaches]. Vodne resursy - Water Resources, 6, 199127 [in Russian]. 
8. Romanenko, V.D., \& Yevtushenko, M.Yu. (2000). Kompleksna ocinka ekologichnogo stanu basejnu Dnipra [Integrated Evaluation of the Ecological Condition of the Dnipro Basin]. Kyiv: Institute of Hydrobiology of the NASU [in Ukrainian].

9. Lisetskii, F.N., Degtyar', A.V., Narozhnyaya, A.G., Chepelev, O.A., Kuz'menko, Ya.V., \& Marinina, O.A. et al. (2013). Basseynovyy podkhod $k$ organizatsii prirodopol'zovaniya o Belgorodskoy oblasti [The Basin Approach to Organizing Nature Management in Belgorod Region]. F.N. Lisetskiy (Ed.). Belgorod: Konstanta [in Russian].

10. Lisetskiy, F.N., Degtyar, A.V., \& Buryak, Zh.A. (2015). Reki $i$ vodnye obekty Belogorya [Rivers and water bodies Belogoriya]. Belgorod: KANSTANTA [in Russian].

11. Ekologicheskoe sostoyanie basseyna Dnepra na territorii Rossii (2009) [The Ecological Condition of the Dnepr Basin on the territory of Russia]. G.M. Chernogayeva, A.S. Zelenov, M.S. Zelenova, Yu.A. Malevanov (Ed.) Moscow: Meteoagency Rossgidrometa [in Russian].

12. Korytnyy, L.M. (2001). Basseynovaya kontseptsiya $\checkmark$ prirodopolzovanii [The basin concept in wildlife]. Irkutsk: Izd-vo Instituta geografii SO RAN [in Russian].

13. Simonov, Yu.G., \& Simonova, T.Yu. (2004). Rechnoy basseyn i basseynovaya organizatsiya geograficheskoy obolochki [The River Basin and the Basin Arrangement of the Geographic Shell]. Eroziya pochv $i$ ruslovye protsessy - Soil Erosion and River-bed Processes, 14, 7-32 [in Russian].

14. Pichura, V.I. (2016). Struktura hidroheomorfolohichnoyi systemy dlya stvorennya heoosnovy ekolohichnoho karkasa baseynu richky Dnipro [Structure of the hydrogeomorphological system for creating the geo-foundation for the ecological framework of the Dnieper river basin]. Dnipropetrovs'koho derzhavnoho ahroekonomichnoho universytetu - Bulletin of Dnepropetrovsk State Agricultural and Economic University, Vol. 2, 40, 19-25 [in Ukrainian].

15. Pichura, V.I. (2016). Sil's'kohospodars'ke porushennya ekolohichnoyi stiykosti baseynu richky Dnipro [Damage to environmental sustainability of the Dnieper river basin caused by agriculture]. Naukovi dopovidi NUBiP Ukrayiny - Scientific reports NUBiP Ukraine, Vol. 5 6. Retrieved from http://journals. nubip.edu.ua/index.php/Dopovidi/article/view/ 7231/7010 [in Ukrainian].

16. Maksimovich, A.M., Leonovich, I.M., \& Koval'chik, N.V. (1985). Otsenka urovnya ntropogenizatsii territorii po izucheniyu rastitel'nogo pokrova [Evaluation of the Level of the Territory Anthropogenization in Exploring Vegetation]. Geograficheskie aspekty ratsional'nogo prirodopol'zovaniya [Geographical Aspects of Rational Nature Management]. Minsk: Nauka i tekhnika [in Russian].

17. Belolipskiy, V.A. (2006). Teoreticheskoe obosnovanie i puti pochvovodookhrannoy optimizatsii grolandshaftov v zone stepi Ukrainy. [The Theoretical Substantiation and the Methods of Soil Conservation Optimization of Agro-landscapes in the Steppe Zone of Ukraine]. Extended abstract candidate's thesis. Kyiv [in Russian].

18. Buryak, Zh.A. (2015). Basseynovaya organizatsiya prirodopol'zovaniya v Belgorodskom ekoregione.
[The Basin Arrangement of Nature Management in Belgorod Eco-region]. Extended abstract candidate's thesis. Moscow [in Russian].

19. Lopyrev, M.I., Shevchenko, V.Ye., Zezyukov, N.I., \& Fedotov, V.A. (1999). Proektirovanie $i$ vnedrenie ekologo-landshaftnykh sistem zemledeliya $v$ sel'skokhozyaystvennykh predpriyatiyakh Voronezhskoy oblasti [Projecting and Implementing Eco-landscape Farming at Agricultural Enterprises of Voronezh region/. M.I. Lopyrev (Ed). Voronezh: Origins [in Russian].

20. Oliinyk, V.S., \& Bielova, N.V. (2014). Erodovanist' zemel' v agrolandshaftah Peredkarpattja [Soil Erosion in Subcarpathia Agro-landscapes]. Geopolitika i ekogeodinamika regionov - Geopolitics and Regional Ecogeodynamics, 10, 2, 361-364 [in Ukrainian].

21. Lisetskiy, F.N., Svetlichnyy, A.A., \& Chernyy, S.G. (2012). Sovremennye problemy eroziovedeniya [The Present Problems of Erosion Science]. A.A. Svetlichnyy (Ed). Belgorod: Konstanta [in Russian].

22. Programma ekologicheskogo ozdorovleniya basseyna Dnepra (2007). [The Program of Ecological Improvement of the Dnepr Basin]. projects.inweh. unu.edu. Retrieved from http://projects.inweh.unu. edu/inweh/getdocument.php? F=1660666292 4baa3e312e05e2.18745111 [in Russian].

23. Pichura, V.I., Lisetskiy, F.N., \& Pavliuk, Ya.V. (2014). Vekovoe izmenenie ustoychivosti agrolandshaftov v zone orositel'nykh melioratsiy sukhostepnoy zony (na primere yuga Khersonskoy oblasti) [The Secular Variation of Agro-landscape Sustainability in the Area of Irrigation Reclamations of the Dry Steppe Zone (Examplified by Kherson Region)]. Nauchnye vedomosti Belgorodskogo gosudarstvennogo universiteta. Estestvennye nauki - The Scientific Bulletin of Belgorod State University. Natural Sciences, 17, 188, 28, 140-147 [in Russian].

24. Voyevodina, L.A. (2011). Vliyanie perepolivov pri kapel'nom oroshenii na meliorativnoe sostoyanie zemel' [The Impact of Over-watering under Drip Irrigation on Land Reclamation Conditions]. Puti povysheniya effektionosti oroshaemogo zemledeliya - The Methods of Increasing Irrigated Agriculture Efficiency, 45, 49-56 [in Russian].

25. Batukaev, A.A., Endovitsky, A.P., Andreev, A.G., Kalinichenko, V.P., Minkina, T.M., \& Dikaev, Z.S. et al. (2016). Ion association in water solution of soil and vadose zone of chestnut saline solonetz as a driver of terrestrial carbon sink. Solid Earth, 7, 2, 415-423 [in English].

26. Kalinichenko, V.P., Yendovitskiy, A.P., Minkina, T.M., Skuratov, N.S., Ilyin, V.B., \& Kim, V.Ch.D. (2014). Upravlenie geokhimicheskimi protsessami v oroshaemykh pochvakh na tekhnologicheskoy platforme noosfery [Management of Geochemical Processes in Irrigated Soils on the Technology Platform of Noosphere]. Prirodoobustroystoo - Nature Arrangement, 3, 6-11 [in Russian].

27. Havrylenko, O.P. (2008). Ekogeografija Ukrai'ny [Ecogeography of Ukraine]. Kyiv: Knowledge [in Ukrainian]

28. Kriukova, N.A., Postolov, V.D., \& Spesivyy, O.V. (2010). Landshaftno-ekologicheskoe obustroystvo zemel' [Landscape-ecological Arrangement of Lands]. Voronezh: FSEI HPE Voronezh SAU [in Russian]. 